\title{
Ett långt liv med särskilda förtecken: Livslopp och åldrande hos människor med funktionsnedsättningar
}

\author{
EVA JEPPSSON GRASSMAN, LOTTA HOLME, ANNIKA \\ TAGHIZADEH LARSSON \& ANNA WHITAKER.
}

Vad innebär det att åldras med funktionsnedsättningar som man fått redan i tidig ålder eller som yngre vuxen? På vilket sätt formar funktionshinder livet över tid? Och hur är det att vara en till åren kommen förälder och fortfarande vara central som hjälpgivare till ett vuxet, funktionshindrat barn? Vilken betydelse har epoken och reformerna? I artikeln diskuteras dessa frågor med utgångspunkt i ett brett upplagt forskningsprojekt "Funktionshinder, livslopp och aildrande"1.

Eva Jeppsson Grassman är professor och verksam vid Nationella institutet för forskning om äldre och åldrande (NISAL), vid Linköpings universitet. Lotta Holme är fil dr och universitetslektor i pedagogik med inriktning mot specialpedagogik. Hon är verksam vid NISAL och Institutionen för beteendevetenskap och lärande vid Linköpings universitet. Annika Taghizadeh Larsson är fil dr i det tvärvetenskapliga ämnet äldre och åldrande och innehar för närvarande en tjänst som postdoktor vid NISAL, Linköpings universitet.

Anna Whitaker är docent i socialt arbete och verksam som forskare och lektor vid NISAL, Linköpings universitet, samt vid Institutionen för socialt arbete, Ersta Sköndal högskola.
1 Projektet "Funktionshinder, livslopp och åldrande" har genomförts med stöd av anslag från Vetenskapsrådet (Dnr: 2005-1056) under ledning av professor Eva Jeppsson Grassman. 


\section{Inledning}

Allmänt sett vet vi förhållandevis litet om funktionshindrade ${ }^{2}$ människors liv över tid och om innebörden av att leva med funktionsnedsättningar under många år, att åldras och vara gammal. Funktionshindrade tillskrivs ofta otydliga och motsägelsefulla identiteter, inte bara beträffande kön utan också beträffande ålder och åldrande (Jeppsson Grassman 2001). Detta kan vara en förklaring till det bristande intresset för att utveckla forskning om funktionshinder med utgångspunkt från begrepp som åldrande och livslopp. Möjligheten till ett långt liv och att åldras med funktionsnedsättningar är också en relativt sentida företeelse. Det är först under efterkrigstiden som vi börjat få identifierbara generationer av individer med funktionsnedsättningar

2 Vår begreppsanvändning följer Socialstyrelsens rekommendationer från 2007-1010: "Nyhet: Bort med termen handikapp. Socialstyrelsens terminologiråd har tagit beslut om revidering av termerna funktionsnedsättning och handikapp. Funktionsnedsättning och funktionshinder är inte längre synonymer, funktionshinder blir en egen term och handikapp utgår. I och med detta definieras begreppet funktionsnedsättning: nedsättning av fysisk, psykisk eller intellektuell funktionsförmåga. Begreppet funktionshinder definieras: begränsning som en funktionsnedsättning innebär för en person i relation till omgivningen. För båda termerna avråds handikapp som synonym. En viktig konsekvens är att funktionshinder inte är något som en person har utan det är miljön som är funktionshindrande."(Socia 1styrelsen, 2007-10-10) orsakade av ett antal olika skador och sjukdomar och som genomlevt olika åldrar och uppnått hög ålder och där livsloppsbegreppet kan framstå som relevant (se exempelvis Strauss \& Shavelle 1998; Mattsson \& Glad 2005; Nilsson m. fl. 2005). Ytterligare ett skäl till bristen på kunskapsutveckling inom det här området kan ha att göra med synen på vad funktionsnedsättningar och funktionshinder är. Det finns en utbredd föreställning om att funktionsnedsättningar är statiska tillstånd (Stiker 1997). Man drabbas av dem, man har dem och man införlivar dem med sin person. Man anpassar sig till dem, så gott det går, med de medel som står till buds - en gång för alla. Samma synsätt gäller för omgivningens anpassning. Samhällsresursernas utformning speglar ofta detta synsätt. Rehabiliteringsprogram har ofta en "en gång för alla" karaktär. "Den funktionshindrade människan" som "den reparerade människan" implicerar att när individen återvunnit "maximal funktionsförmåga" finns det inga ytterligare konsekvenser kvar i form av ytterligare försämrad funktionsförmåga, till exempel på grund av tilltagande sjukdomskomplikationer (Stiker 1997; Williams \& Busby 2000). Både handikappforskningen och den sociologiska sjukdomsforskningen har tenderat att framför allt intressera sig för det kortsiktiga tidsperspektivet (Bury 2000; Jeppsson Grassman 2003; Priestley 2003).

Funktionshindrade är inte någon homogen grupp. Funktionsnedsättningen kan vara medfödd eller förvärvad, tidigt eller senare i vuxenlivet. Den kan vara orsakad av skada, eller - som mycket ofta är fallet - en konsekvens av kronisk sjukdom. Livs- 
situationen varierar för grupper av funktionshindrade beträffande problembild, sjukdomskomplikationer och överlevnadschanser. Icke desto mindre finns det också en hel del förhållanden som de delar. Zarb (1993), som studerat livsvillkor för människor som levt länge med funktionshinder, konstaterar att även om det finns likheter mellan dem och andra, icke-funktionshindrade grupper i samma åldrar, har funktionshindrade också egna erfarenheter formade av livet med funktionsnedsättningen. Jeppsson Grassman har gjort motsvarande iakttagelser (2001; 2003). Dessa erfarenheter får betydelse för hur till exempel pensionärstillvaron kommer att gestalta sig.

Inte bara i Sverige utan även i Västvärlden i stort börjar man nu efterfråga kunskaper när det gäller funktionshinder och åldrande, inte minst för planering av boende och omsorg. Men den kunskap som hittills funnits, exempelvis inom socialgerontologin, har som regel rört frågor kring funktionsnedsättningar hos äldre snarare än hur det är att leva under många år och åldras med funktionshinder (Avlund 2004). På motsvarande sätt har det hittills saknats forskning och kunskap om vad det innebär att under många år av sitt liv vara anhörig till en funktionshindrad person, i behov av hjälp (DeMarle \& Le Roux 2001; Jeppsson Grassman, Whitaker \& Taghizadeh Larsson 2009).

\section{Livslopp och åldrande}

Vad betyder det att studera funktionshindrades liv och åldrande ur ett livsloppsperspektiv? Det innebär att man intresserar sig för innebörden av funktionsnedsättningen i ett sammanhang av hela livets dynamik, och utifrån ett synsätt där åldrande ses som en livslång process. Likaså blir det betydelsefullt att placera in händelser förknippade med funktionsnedsättningen $\mathrm{i}$ individens egen biografi och i den process av ständigt pågående förändring som livet är. Centrala frågor blir när i livet individen fått sin funktionsnedsättning, under hur lång tid hon/han haft funktionsnedsättningen, hur den påverkat livets olika faser och roller och hur gammal den individ är som ser tillbaka på erfarenheten av att leva med funktionshinder.

Tidsbegreppet får en mångdimensionell betydelse vid denna typ av förståelse. Det gäller inte minst eftersom den epok - den historiska tid - som individens liv utspelar sig i, också har en central betydelse för perspektivet. Individens biografi kan ses som formad genom samspelet mellan individens tid och händelser, och förhållanden relaterade till den historiska tid under vilken hon/han lever. Individens lokalisering i historien, dvs. i tid och rum, får inverkan på hur hennes liv kommer att gestalta sig (Giele \& Elder 1998). Kohortbegreppet är här centralt. Individens ekonomiska förutsättningar, kön och hälsa är exempel på förhållanden som differentierar innebörden i den historiska lokaliseringen. Även familje- och generationsrelationer har betydelse och bidrar i stor utsträckning till att forma individens livslopp (Hareven 2000; Mills 2000).

Livsloppet kan beskrivas som individens åldersindelade mönster av utveckling "inbäddat" i sociala institutioner under en viss historisk epok (Levy 1996; Elder Jr., 
Kirkpatrick Johnson \& Crosnoe 2003; Kohli 2005). Oavsett utgångspunkt kan man se det som att livsloppet och dess faser får en personlig, individuell utformning, men som också påverkas av institutionaliserade normer kring livets faser och åldrar, dvs. ett slags etablerade sociala tidtabeller, som kan vara mer eller mindre fixerade och allmängiltiga eller tidsbundna (Närvänen 2004). Normalitetsbegreppet fungerar här som en underliggande kompass.

När livsloppsbegreppet (engelskans life course) diskuteras sker det just oftast implicit, med utgångspunkt från "typiska", normalt institutionaliserade livslopp. Behovet av att studera det otypiska eller avvikande för att fördjupa kunskapen har dock påpekats (Trieschmann 1987; Ansello \& Eustis 1992; Zarb 1993; Jeppsson Grassman 2003; Leisering 2003). Överhuvudtaget finns anledning att problematisera "det normala" i fråga om livslopp, och utifrån olika perspektiv (Bury 2000; Hockey \& James 2003; Jeppsson Grassman \& Olin Lauritzen 2004; Whitaker 2004).

Forskning med utgångspunkt från livsloppsbegreppet har, allmänt sett, expanderat påtagligt under de senaste 25 åren. Kunskapen är dock otillräckligt utvecklad när det gäller funktionshinder och åldrande ur ett livsloppsperspektiv. Den forskning som finns har i hög grad fokuserat på enskilda livsfaser och åldrar (Verbrugge \& Yang 2002; Priestley 2003). Vi vet förhållandevis litet om funktionshindrade människors liv över tid och om innebörden av att leva med funktionshinder under många år. Några undantag är Zarb och Oliver (1993), Priestley (2003), Putnam (2002) samt Jeppsson Grassman $(2001 ; 2003$; 2008) som studerat dessa frågor. På motsvarande sätt saknas forskning om vad det innebär att under många år av sitt liv vara förälder, syskon eller make till en funktionshindrad person (i behov av hjälp). Funktionshindret är något som inte bara påverkar den enskilde utan $i$ högsta grad bidrar till att forma livsloppet för samtliga personer i en familj (DeMarle \& Le Roux 2001). Ett gryende intresse för frågor som berör funktionshinder och åldrande liksom livslopp och funktionshinder kan skönjas internationellt (Kennedy 2002). Vår avsikt med det forskningsprojekt, på vars ansats och resultat diskussionen i denna artikel är baserad, har just varit att bidra med ny och relevant kunskap inom detta forskningsfält under utveckling.

Syftet med artikeln är att diskutera funktionshinder och åldrande ur ett livsloppsperspektiv. Följande frågor tas upp: Vad innebär det att åldras med funktionsnedsättningar som man fått redan i tidig ålder eller som yngre vuxen? På vilket sätt formar funktionshinder livsloppet över tid? Vilken betydelse har epoken och reformerna? Hur är det att vara en till åren kommen förälder och fortfarande vara central som hjälpgivare till ett vuxet, funktionshindrat barn?

\section{Material och metod}

I forskningsprojektet "Funktionshinder, livslopp och åldrande" har den centrala forskningsfrågan handlat om hur livet gestaltat sig för människor med fysiska funktionsnedsättningar som vuxit upp och framlevt sitt vuxenliv under vissa historiska betingelser, med speciellt fokus på samspelet mellan personliga innebörder och institu- 
tionella förhållanden och diskurser som har att göra med funktionshinder, ålder och åldrande. Då en given utgångspunkt för projektet har varit att erfarenheten av att åldras med funktionshinder är något som inte enbart formar den enskildes liv utan något som påverkar livsloppet för hela familjen, har projektet även rymt ett anhörigperspektiv inom vilket forskningsfrågan studerats på motsvarande sätt. Den historiska epok som är projektets fond är perioden efter 1960 och fram till vår tid.

Projektet består av fyra delstudier. Tre har retrospektiva ansatser medan delstudie 4 har haft en uppläggning av omfattande datainsamling över en 25-årsperiod. I delstudie 1 har den moderna handikapprörelsens pionjärer studerats, med fokus på deras engagemang $i$ och syn på den handikappolitiska utvecklingen. Intervjuer har genomförts med sju personer som levt med funktionshinder under många år och samtidigt haft en medskapande roll i handikappolitiken. I delstudie 2 har relationen mellan diskurser om ålders- och livsfaser i handikappolitiken och det levda livet studerats - dvs. hur de funktionshindrade som varit föremål för politiken beskriver sina liv och sitt åldrande. Intervjuer har gjorts med 20 funktionshindrade personer som idag befinner sig i 60-70 årsåldern. I delstudie 3 har innebörden av att vara anhörig till en funktionshindrad person, sett över tid, studerats samt hur detta anhörigskap har påverkats av de handikappolitiska förändringsprocesser som skett i Sverige under de senaste decennierna. Intervjuer har genomförts med 12 föräldrar och 4 syskon till fysiskt funktionshindrade personer födda mellan 1950 och 1980. Delstudie 4 utgörs av en 25-årsuppföljning av en prospektiv livsloppsstudie i vilken en grupp om 14 kroniskt sjuka, synskadade personer följts sedan 1981. Speciell tonvikt har här lagts vid frågor om kropp, sjukdom och åldrande mot bakgrund av samhällsdiskurser om ålder och delaktighet. I delstudierna 1-3 har omfattande intervjuer genomförts vid ett tillfälle. I delstudie 4 har intervjuer genomförts vid fem tillfällen.

Delstudierna bygger i huvudsak på intervjuer med delvis ganska olika populationer av människor med kroniska sjukdomar och/eller funktionsnedsättningar, men där vissa avgränsningar är gemensamma: Det är fråga om människor ur några olika (födelse)kohorter, de äldsta födda ungefär 1935 och de yngsta omkring 1950. De intervjuade föräldrarna i delstudie 3 är födda mellan 1922 och 1955. Projektet har varit avgränsat till personer med fysiska funktionsnedsättningar och som levt med funktionshinder under flera decennier. Funktionsnedsättningens karaktär och yttringar har förstås betydelse för de erfarenheter som återges i de olika delstudierna, men de enskilda diagnoserna/sjukdomarna/funktionsnedsättningarna har inte stått i centrum för vare sig projektets utgångspunkter eller analyser. ${ }^{3}$

De olika delstudiernas empiri har analyserats samlat med syfte att tydliggöra olika teman som är unika och situationsbundna men också av mer gemensam karaktär.

3 De intervjuade i delstudierna 1-3 hade fysiska funktionsnedsättningar orsakade av bl. a. medfödda nedsättningar, ryggmärgsbråck, polio, cerebral pares, multipel skleros och av ett antal mindre kända sjukdomar. 


\section{Resultat}

Resultaten från de fyra delstudierna uppvisar både olikheter och likartade mönster i förhållande till de frågeställningar och perspektiv som projektet fokuserar. Här redovisas resultat som belyser några centrala tematiska områden med anknytning till livslopp och åldrande för de studerade grupperna. Det är fråga om epoken och reformerna, vidare handlar det om ålder, äldreblivande och den långa tiden, liksom om kroppen och om oron för framtiden. Slutligen belyses pensionärslivet.

\section{Epoken och reformerna}

Tiden från 1960 och fram till vår tid har varit en dynamisk period som innefattar välfärdsstatens expansion och relativa tillbakagång liksom den fulla sysselsättningens tid och ideal. Epoken inrymmer också civilsamhällets expansion där många organisationer uppstått som ett resultat av patientgruppers, funktionshindrades och anhörigas engagemang i sociala frågor. Under denna epok har en hel del viktiga reformer genomförts på det handkappolitiska området, i syfte att skapa möjlighet för funktionshindrade att få delaktighet i samhällslivet och så "normala" livslopp som möjligt. De första moderna handikappolitiska tankegångarna introducerades i början av 1960-talet, genom "normaliseringsprincipen", då nytt och på sitt sätt revolutionerande. Det "miljörelativa" handikappbegreppet fick starkt genomslag på 1980-talet och har sedan haft fortsatt stor betydelse. Genom detta synsätt flyt- tas "handikapp" från individen till omgivningen och sägs uppstå i relation till omgivningen och dess bristande anpassning till individen. År 1994 trädde Lagen om stöd och service till vissa funktionshindrade (LSS) i kraft liksom Lagen om assistansersättning (LASS). Lagarna innebär bland annat att personer med omfattande funktionsnedsättningar har fått rätt till personlig assistans. Ett uttryck för dagens handikappolitik och handikapprörelse är den nationella handlingsplanen Från patient till medborgare - en nationell handlingsplan för handikappolitiken som riksdagen antog år 2000. Handlingsplanen kan sägas vara ett slags programförklaring där målet är full delaktighet och jämlikhet i samhället för funktionshindrade. Funktionshindrade ska ha samma medborgerliga rättigheter och skyldigheter som alla andra. Frågor som särskilt ska fokuseras är tillgänglighet och bemötande (Regeringens proposition 1999/2000:79). Lagstiftningen har således gått från att reglera samhällets skyldigheter till att även omfatta individens rättigheter och förbud mot diskriminering (SFS 2008:567).

Vad kan det ha inneburit att leva och åldras med svåra funktionsnedsättningar under den beskrivna epoken? Det har varit en central fråga i samtliga våra delstudier. Det har skett viktiga genombrott i synsätt och viktiga landvinningar när det gäller konkret politik och reformer, men har de haft betydelse i de intervjuades liv? Frågan har naturligtvis inget enkelt svar och den bild som analysen förmedlar är ganska mångtydig. Uppfattningarna om vad man lyckats uppnå och inställningen till det handikappolitiska arbetets relativa fram- 
gångar varierar bland informanterna $\mathrm{i}$ de olika studierna, bl.a. beroende på ålder, typ av sjukdom och funktionsnedsättning, men också beroende på den egna positionen i förhållande till samhällsutvecklingen. Exempelvis menar de intervjuade i delstudie 1 - personer som varit aktiva, ledande eller på olika sätt framstående inom handikapprörelsen under denna handikappolitiskt dynamiska epok - att de handikappolitiska framgångarna varit stora, men att vägen mot full delaktighet i ett tillgängligt samhälle också varit kantad av motgångar. Människor som har ett starkt handikappolitiskt engagemang har många gånger tillägnat sig en gemensam eller kollektiv berättelse om handikapprörelsens moderna historia och dess landvinningar. I denna framstår det miljörelativa handikappbegreppet, LSS- och LASS-lagarna och även den ökade tillgängligheten i samhället som milstolpar på vägen mot större delaktighet. Särskilt LSS-lagstiftningen förefaller ha stor symbolisk betydelse som en ideologisk brytpunkt i handikapphistorien. Skiftet innebar att som funktionshindrad byta från en identitet som objekt till att vara subjekt $i$ sitt eget liv, menar de. Den personliga assistansen ökade möjligheterna för ett så kallat normalt livslopp.

I övriga delstudier framkom mönster som speglade andra positioner och delvis andra erfarenheter. Många av de intervjuade drabbades i yngre vuxenålder av allvarliga funktionsnedsättningar eller komplikationer av kroniska sjukdomar. För dem visade sig reformer på arbetsmarknadsområdet ha varit en förutsättning för att överhuvudtaget kunna ha ett fortsatt arbetsliv. Men "rätten till arbete" kunde uppfattas som villkorad: omfattande arbetsinriktad rehabilitering kunde man få en gång, möjligen två. Men om ytterligare skador sedan tillkom som påverkade funktionsförmågan tycktes omgivningen ofta "tröttna". Det gällde inte minst myndigheterna, framkom det i ett antal intervjuer. Att "ha ett arbete" visade sig inte heller vara samma sak som att vara delaktig. Ett vanligt återkommande mönster handlade om upplevelsen av att "sitta av tiden" på en arbetsplats där man egentligen inte behövdes.

LSS-lagstiftningen hade dock faktiskt radikalt förändrat livet för de med de svåraste funktionsnedsättningarna bland våra intervjuade och i många avseenden tycks lagstiftningen utgöra en vändpunkt i deras liv och möjligen skulle vi här kunna tala i termer av ett slags positivt biografiskt brott (se Bury 1982). Det blir särskilt tydligt ur ett längre tidsperspektiv, där ett mönster i berättelserna var "före och efter LSS":

Uno, som fölits $i 25$ år inom den prospektiva delstudien, och som var 62 år vid det sista intervjutillfället (2006), var en av de som genast efter LSS-lagstiftningens genomförande hade "kastat sig på telefonen" för att ansöka om personlig assistans. När han nu såg tillbaka på de gångna 10 åren konstaterade han att "LSS har förändrat hela mitt liv... verkligen. Tidigare kom jag ju knappt utanför dörren".

"Före och efter" gällde inte bara assistansreformen. Det kunde också gälla exempelvis utvecklingen när det gäller tekniska hjälpmedel och möjligheten till handikappidrott: Göran, 67 år, berättade om hur han sedan ungdomen varit mycket idrottsintresserad. 
På den tiden fanns det emellertid inga möjligheter för honom att idrotta själv. I dag, betydligt äldre och med mer omfattande funktionsnedsättningar, tog han tillfället i akt att pröva många av de idrotter som för första gången är tillgängliga för personer som exempelvis använder rullstol.

Men, å andra sidan, trots de reformer som genomförts i syfte att möjliggöra för funktionshindrade att ha ett självständigt och aktivt liv, så visar vår studie av åldrande föräldrar till vuxna funktionshindrade barn att det övergripande omsorgsansvaret i många fall förblivit förälderns genom hela livet, även efter assistansreformen. Detta omsorgsansvar kunde ta sig lite olika uttryck. En vanlig roll var att som förälder gå in som personlig assistent åt sitt vuxna barn, en annan roll handlade om att vara "stötdämpare", vilket innebär att ta de krävande myndighetskontakterna, överklaga beslut etc. Den kanske vanligaste rollen och som inte på något sätt verkade avta med tiden var föräldrarnas roll som "jour":

Föräldrarna var beredda - dygnet runt att rycka ut när exempelvis assistenter inte dök upp, och vikarier inte gick att ordna. För flera av de intervjuade hade denna jourberedskap varit konstant. "Jag har haft jouren varje dag i 37 år."

Anhöriga tycks överhuvudtaget ha en betydligt centralare roll för stöd och omsorg än vad som framkommit i tidigare forskning (jfr Whitaker 2008; Jeppsson Grassman, Whitaker, Taghizadeh Larsson 2009).

\section{Ålder, äldreblivande och den långa tiden}

Flertalet av de intervjuade hade uppnått en relativt hög ålder. Samtidigt hade de levt $\mathrm{i}$ många år med funktionshinder, något som präglat åldrandeprocessen. Till vardags används begreppen ålder och åldrande ofta på ett förgivet taget sätt, utan närmare precisering. I projektet har ålderns och åldrandets sociala betydelser bland annat utforskats genom att uppmärksamhet riktats mot äldreblivandet och mot vad sociala åldersnormer kopplade till denna del av livsloppet kan betyda för funktionshindrade. Äldreblivandet, det vill säga övergången till den del av livsloppet då människor blir ålderspensionärer och $i$ många sammanhang börjar kategoriseras som äldre, finns knappast belyst i handikappforskningen men har tydligt reglerats i lagstiftningen när det gäller stödinsatser till funktionshindrade. Arbetslivet har en påtagligt normerande betydelse.

Ett återkommande mönster var att de intervjuade uttryckte en medvetenhet om att det egna arbetslivet på många sätt kommit att avvika från det åldersförväntade inte minst eftersom de lämnat arbetslivet så tidigt. Att bli ålderspensionär kunde därmed i någon mån få en normaliserande funktion. Samtidigt var det så att övergången till ålderspension fått påtagliga ekonomiska konsekvenser för flera av dem som lämnat yrkeslivet långt innan de fyllt 65 . Utöver att liv med funktionshinder många gånger innebär särskilda kostnader (Zarb \& Oliver 1993; Socialstyrelsen 2008) och kan innebära svårigheter att få och/ 
eller behålla ett yrkesarbete, hänger arbetslivets längd samman med ålderspensionens storlek. Men äldreblivandet framträdde inte som odelat negativt för alla. Ett antal mer positivt eller neutralt laddade teman i flera av intervjuerna kan förstås som åtminstone till en del relaterade till åldersnormer. Det rör sig om normer som säger att i åldrarna kring 65 och därefter inte "hör till" på samma sätt som i yngre vuxenålder att yrkesarbeta eller att framstå som "fit for production and reproduction" (Priestley 2004, sid. 95). Flera av de intervjuade som var i 55-70-årsåldern hävdade att de inte längre brydde sig lika mycket om huruvida de uppfattades som utseendemässigt (o) attraktiva eller annorlunda av andra. Flera gav också uttryck för att de inte längre fann det lika befogat att anstränga sin kropp på det sätt de gjort tidigare i livet, inte minst i arbetslivet och i rollen som förälder. "Jag måste inte bevisa en massa saker. Det är inte så viktigt nu, jag duger som jag är" förklarade en kvinna.

Några av dem som var kvar i arbetslivet eller som arbetat fram till ålderspensionen beskrev övergången till ett liv som pensionär "som en befrielse", samtidigt som det faktum att de kunnat eller planerade att arbeta fram till 65, eller nästan ända fram, framträdde som en tillfredsställande bekräftelse på normalitet. Men att lämna arbetslivet och gå i pension kunde också upplevas som värre för funktionshindrade än vad man antog att det var för icke funktionshindrade, eftersom man tyckte att arbetet motverkade känslan av diskriminering. Viktigt att understryka är också att utsagorna om att man idag förhöll sig till sin situation på andra sätt än tidigare i livet inte bara kan förstås i termer av ålder och åldersnormer. Mönster i de genomförda delstudierna visar snarare hur intimt sammanvävda eventuella åldersfenomen är med andra tidsdimensioner. Inte minst är det svårt att separera betydelsen av social ålder från att de intervjuade har levt med omfattande funktionsnedsättningar under lång tid och från de specifika erfarenheter som följer med detta faktum.

Ett övergripande intryck från delstudierna är att när det gäller de intervjuades syn på sig själva, andra och sin position $i$ samhället idag framträder åldern och åldrandets betydelser som underordnad den lainga erfarenheten av funktionsnedsättningar och funktionshinder. Det överensstämmer med resultat från Zarbs och Olivers (1993) brittiska studie om att åldras med fysiska funktionsnedsättningar. De kommenterar hur deras biografiska data indikerar att erfarenheten av att vara "äldre" (older people) inte kom i närheten av betydelsen av "their collective experience built around the prior experience of disability" (s. 59). I våra studier resonerade individerna i stor utsträckning utifrån sin egen och andras situation som funktionshindrade, och man jämförde sig inte nödvändigtvis med "icke funktionshindrade" människor $i$ samma ålder. Så här sammanfattade exempelvis Gunnar sitt liv och sin situation:

Det är väl bara att säga det att jag har haft en otrolig tur. När jag ser på mina vänner med samma diagnos som har fätt de dråpligaste situationer i livet. De kan inte prata, många har försvunnit bort helt enkelt.

Det sociala åldrandet och den långa erfa-

Jeppsson Grassman, Holme, Taghizadeh Larsson \& Whitaker: Ett långt liv... 
renheten av funktionshinder har i projektet sammanfattningsvis framträtt som två komponenter av betydelse för individer $i$ åldrarna kring 65 som under en stor del av sina liv levt med funktionshinder och i det "scenario" utifrån vilket individen upplever, tolkar, värderar och hanterar sin situation.

\section{Kroppen}

Under den studerade epokens första del dominerade fortfarande den medicinska modellen när det gällde synen på funktionsnedsättningar. Den tar sin utgångspunkt i den individuella skadan och fokuserar framför allt de kroppsliga begränsningarna som individen anses "ha". Om inte tillfrisknande kan åstadkommas är det ändå individens egna ansträngningar som är vägen till förbättrad funktionsförmåga. Det miljörelativa synsättet, som slog igenom i början av 1980-talet, med dess betoning på samhällets och miljöns roll i funktionshindrande processer, har, mot denna bakgrund, varit mycket viktigt för att åstadkomma rättmätiga samhällsförändringar för berörda grupper. Men kanske har det miljörelativa synsättet blivit för ensidigt, åtminstone i forskningen, något som tenderat att osynliggöra vissa viktiga aspekter av funktionshindrades liv och erfarenheter?

Resultaten från våra studier tyder på att så är fallet när det gäller hur man kan förstå innebörden av sjukdomen och funktionsnedsättningen. Upplevelsen av den skadade/sjuka kroppen "försvinner" inte genom miljöanpassande synsätt och åtgärder för delaktighet, något som också andra forskare pekat på (Hughes \& Paterson 1997; Williams \& Busby 2000; Thomas 2002). Det visade sig vara viktigt att inkludera den kroppsliga erfarenheten $i$ analysen för att förstå vad det innebar att leva med funktionshinder och att detta blev särskilt tydligt ur det långa tidsperspektivet. I de intervjuades berättelser om sina liv framstod kroppen ofta som ett centralt tema: den skadade, sjuka kroppen som man har att leva med och kämpa emot. Gemensamt för de individer vi studerat är dessutom att ingen av dem tycks ha haft någon stabil funktionsförmåga. Detta trots att flera av dem har diagnoser som cerebral pares eller ryggmärgsskador som ofta framställs som just stabila (SOU 1991:46; Williams 2000). I andra fall handlar det om funktionsnedsättningar orsakade av kroniska sjukdomar med ständig risk för tilltagande problem och komplikationer till grundsjukdomen:

Karin (65 år) är synskadad till följd av diabetes hon haft sedan barndomen. Sedan vi sågs senast har hon opererat händer och fötter och fätt bypass-operationer $i$ benen $p a$ grund av dålig blodcirkulation. I förbigàende nämner hon också att hon, ett par år tidigare, brutit lårbenshalsen och en axel när hon ramlade till följd av ett insulinkoma.

Nästan samtliga föräldrar till vuxna funktionshindrade berättade om hur barnet redan som litet fick genomgå flera svåra operationer, smärtsamma behandlingar och separationer på grund av långa sjukhusvistelser, men hur det också senare och fortlöpande i vuxenlivet tillstött komplikationer av skilda slag som lett till svåra behand- 
lingsperioder och ibland operationer. Med åldern tilltog en del tillstånd såsom ökad slembildning, ökade andningssvårigheter, ökad muskelsvaghet, sämre blodcirkulation, ökad risk för sittsår, samt svårläkta infektioner med amputationer till följd.

Tillvaron får därför karaktären av en ständigt pågående förändringsprocess där funktionsförmågan är provisorisk och oviss. Många sjukdomar förvärras med åren - med åldern i viss mån, men framför allt med den långa tiden med sjukdomen. Att iaktta kroppen och "stämma av" hur den fungerar blev för vissa en taktik för att ha kontroll i vardagen. Man kanske kan tro att den som är multisjuk och funktionshindrad så småningom "vänjer sig" och lättare kan hantera nya komplikationer till sin grundsjukdom. Det fanns inte något sådant entydigt mönster i resultaten. Tvärt emot vad nog många tänker sig, var det få av de intervjuade som gav uttryck för att vare sig deras förhållandevis höga ålder eller den långa erfarenheten av att leva med funktionshinder medfört att man idag upplevde försämringar av den egna hälsan och funktionsförmågan som mindre besvärliga än tidigare. Vanan väger inte upp förlusten. Flera beskrev och tolkade visserligen en del av de försämringar som ägt rum under senare år som åldersrelaterade. Men nytillkomna eller befarade funktionsförsämringar beskrevs också av många av de intervjuade i dramatiska och känslomässiga termer och som hot mot aspekter av det egna livet som man värderade högt. Livssituation för flertalet intervjuade karaktäriserades av ett antal krisrelaterade omställningar utspridda över livsloppet.
Bury (1982) myntade begreppet "biographical disruption" - biografiskt brott eller livsbrott. Begreppet har fått stark genomslagskraft när det gäller att begreppsliggöra sjukdom som ett oväntat avbrott i det pågående livsloppet, något som inte bara får praktiska konsekvenser utan också djupgående betydelse för identiteten och föreställningarna om det egna framtida livet. Detta suggestiva begrepp ger dock associationer till en stor, oväntad händelse. Livsbrottsbegreppet framstår inte som helt relevant för att beskriva de sjukdomsrelaterade erfarenheter som präglar de intervjuades livslopp (se också Taghizadeh Larsson 2009). "Man vet aldrig hur länge det håller", sade en intervjuad och uttryckte något som var mycket vanligt förekommande i berättelserna. De intervjuade levde med ett slags dubbla synsätt där nya sjukdomskomplikationer är både förväntade och oväntade händelser.

\section{Oronförframtiden}

En omfattande handikappolitik till trots så var ändå oron för framtiden ett mycket vanligt förekommande tema i intervjuerna: Den kunde gälla mycket konkreta förhållanden. Bland de intervjuade som hade personlig assistans gavs exempelvis uttryck för en osäkerhet om hur det skulle bli med hjälpen i framtiden: Hur länge sträckte sig egentligen den förlängning man fått? Vad skulle hända när man behövde hjälp fler timmar än vad man nu hade? Centralt i oron var kroppen: Oron för att förlora den lilla funktionsförmåga man fortfarande hade kvar, oro för ännu svårare sjukdoms-

Jeppsson Grassman, Holme, Taghizadeh Larsson \& Whitaker: Ett långt liv... 
komplikationer, för förlust av viktiga anhöriga som hjälpgivare och - för en för tidig död. I flera av intervjuerna föreföll det som om denna oro ökade allt eftersom tiden gick, ett större antal år med funktionshinder och en gradvis alltmer skadad kropp kunde läggas till livet. De osäkra framtidsutsikterna rymmer en hög medvetenhet om att "livet är kort". En intervjuad uttryckte sina funderingar på följande vis:

Komplikationerna ... att man inte vet hur fort det går ... Hur många år jag har kvar och i vilken takt de kommer att gå ... Varje försämring ... då undrar man hur länge till ... om det kan stanna så här ett tag nu".

Men detta tema varierade $\mathrm{i}$ intensitet mellan individer, men också över tid. På motsvarande sätt oroade sig de åldrande föräldrarna som intervjuades för sin egen vacklande hälsa och "omsorgsork". Åldrandet innebär förändringar på flera plan. Funktionsnedsättningen, sjukdomsbilden, prognosen tillsammans med åldrandet gör framtiden osäker. Det är nödvändigtvis inget nytt för föräldrarna. Livet med ett barn med svåra funktionsnedsättningar har egentligen hela tiden inneburit ett visst mått av osäkerhet, och en försiktighet med att planera för framtiden. Men detta accentueras i takt med åldrandet. En tanke som delades av många - framför allt av dem som inte hade fler barn - var att de som föräldrar inte kan eller får dö före barnet. Det är en tanke förbunden med ovissheten över hur livssituationen för det funktionshindrade vuxna barnet kommer att se ut framöver och för flera är det direkt ångestväckande:
"Det är ju ångest alltså, inte så lite heller. Det är en stor ångest och det finns lite det bland föräldrar att vi inte fär dö. Vi måste leva hela tiden på nåt sätt ..."

Men lika ofta beskrev föräldrarna hur de samtidigt förberedde sig på att barnet, på grund av sin funktionsnedsättning och av de komplikationer som tillstöter med åldern, faktiskt kunde dö före föräldern. Överhuvudtaget framstår oron inför framtiden och upplevelsen av den korta tid som återstår, som upplevelser direkt förknippade med kroppen. Med kroppen som utgångspunkt, med funktionsnedsättningarnas instabila och minst sagt oförutsägbara karaktär bedöms framtiden inte bara för den funktionshindrades liv, utan också för familjens, för föräldrarnas liv.

En annan strategi som återfanns i intervjuerna var att leva med "dubbla agendor", det vill säga att man tänker på framtiden i ett både ett kort och ett långt tidsperspektiv. Trots medvetenheten om och att man på något plan försökte förebereda sig på att livet inte skulle bli så långt, planeras samtidigt för framtiden. De intervjuade föräldrarna såg bland annat som sin uppgift att "bädda för framtiden", det vill säga att på olika sätt skapa bästa möjliga förutsättningar kring det vuxna funktionshindrade barnet innan de själva blev för gamla, sjuka och dör. Hur personlig assistans och annat stöd från samhället fungerar är en viktig faktor för hur framtiden ses an. Men lika viktigt i detta avseende är tillgången till nära anhöriga och andra betydelsefulla sociala kontakter. 


\section{Ett pensionärsliv som andras?}

Av de intervjuade var drygt 2/3 över 65 år vid intervjutillfället. ${ }^{4}$ Hur är det att bli gammal och leva som pensionär om man har levt ett långt liv med funktionshinder? Präglas tillvaron av ett slags" dubbelt annorlunda" eller normaliseras livet i takt med åldern och blir mer likt andra pensionärers liv? Svaret är att det tycks kunna vara fråga om båda förhållandena. Svaren varierade mellan individer. Det var högst personliga pensionärsliv det är fråga om. I vissa avseenden tycktes livet bli mer likt andras. I andra avseenden förblev livet starkt präglat av den annorlunda erfarenhet som den långa tiden med, ofta tilltagande, funktionsnedsättningar innebär.

Som en röd tråd genom många intervjuer gick också ett antal existentiella teman som hade att göra med förhållningssätt i en livssituation präglad av stor osäkerhet och många kroppsliga förluster. "Det borde inte vara någon skillnad", som en bland handkapprörelsens pionjärer uttryckte det: Hon ansåg att funktionshindrades äldreliv inte egentligen borde skilja sig så mycket från icke funktionshindrades, om man hade personlig assistans. Men i praktiken var det skillnad. Resultaten visade att många av de intervjuade levde med funktionsnedsättningar som var svårare än 20 år tidigare och som begränsade livet påtagligt, även om livet nu kunde upplevas som friare, till exempel från arbetslivets plikter. Före-

4 När det gäller den prospektiva delstudien avses här det sista intervjutillfället. komst av funktionsnedsättningar tilltar allmänt sett med åren men här är det fråga om de sista faserna i en kanske nästan livslång process. Att fortfarande klara av framträdde som ett viktigt mönster - att röra sig ute, delta i föreningsaktiviteter, etc. För några av de nyblivna ålderspensionärerna som lämnat arbetslivet långt innan de fyllt 65 framstod äldreblivandets normer som relativt betydelselösa. De hade varit pensionärer i så många år att detta blivit det normala. Hur pensionärslivet blev hade också att göra med de val man gjort mycket tidigare i livet.

För de handikappolitiskt aktiva, som fokuserats i projektets delstudie 1 , hade livet präglats av arbete " $i$ handikapprörelsens tjänst". Deras livsberättelser vittnar om att det handikappolitiska arbetet kan vara en mycket viktig del $i$ en människas identitet. Organisationerna stärkte deras positiva och kollektiva identitet som funktionshindrade, men samtidigt var de hänvisade till sammanhang som rörde endast funktionshindrade, vilket innebär något av en handikappolitisk paradox. Resultatet blev ett slags "instängd" identitet, som också påverkade det pensionärsliv man nu levde.

Och för de intervjuade föräldrarna till vuxna, funktionshindrade barn, innebar pensioneringen snarast att det blev särskilt tydligt att det egna livet inte följer de socialt normativa tidtabellerna eller rollerna. Det "otypiska pensionärslivet" tydliggörs kanske än mer i takt med åldrandet och i relation till föreställningar om ålderdom och familjens roller och omsorgsansvar mellan generationerna. När man är 68 ska man ha barnbarn, när man är 85 och börjar bli lite

Jeppsson Grassman, Holme, Taghizadeh Larsson \& Whitaker: Ett långt liv... 
skröplig finns förväntningar om att det egna barnet ska kunna vara ett stöd. Det är mot den här typen av normativa föreställningar om åldrandet och pensionärslivet som flera av de intervjuade föräldrarna ställde sina egna livslopp. I stället konstaterar de att omsorgsansvaret ännu pågår, att det inte blir några barnbarn och att det egna barnet inte kommer att kunna ge något praktiskt stöd den dag föräldern behöver det. Vuxenföräldraskapär ett begrepp som introducerades av några av intervjupersonerna för att tydliggöra de speciella erfarenheter och konsekvenser som just är förknippade med att ha ett vuxet funktionshindrat barn. Med dessa erfarenheter följer ett levnadslopp och ett pensionärsliv som inte riktigt är som andras:

... så nu när mina kompisar börjar få barnbarn och man tänker att vi har varit upptagna med barn, men nu är de upptagna med barnbarnen så att ... och jag står liksom kvar på samma, förstår du hur jag menar? Och det kan jag också känna, de har ju barn som börjar bli stöd för dem och jag ska fortfarande vara stöd för min son sen, och så känner jag att krafterna börjar ta slut ...

Barnlösheten hos många av de intervjuade funktionshindrade i övriga delstudier tycktes kunna leda till liknande funderingar kring åldrande och familjeroller. Men för vissa intervjuade, och på andra områden, visade sig livet vara överraskande likt ett "vanligt" pensionärsliv, om än med lite speciella förtecken. Till exempel visade det sig idag möjligt att leva ett aktivt, självförverkligande "tredje-åldern liv", även för personer som behöver hjälp med exempelvis förflyttningar och på- och avklädning, vilket framgår av våra resultat. En del bland de intervjuade ålderspensionärer som har personlig assistans beskrev hur de gick på teater och konserter, ägnade sig åt eget konstnärskap, var föreningsaktiva, gymnastiserade, arbetade (handikapp)politiskt och/eller reste. Det fanns också de som gav uttryck för att ägna sig åt självförverkligande. Exempelvis berättade en kvinna om hur hon som ung sökt in och blivit antagen vid en konsthögskola. Men utbildningen var vid den tiden belägen fyra trappor upp, utan hiss, vilket gjorde det omöjligt för henne, som även då använde rullstol, att ta sin plats i anspråk. I dag ägnade hon däremot en hel del av sin tid åt konstnärlig utövning i olika former och var aktiv medlem i en konstförening. Flera intervjuade påtalade att man också uppfattades som mer "vanlig" av omgivningen, nu när man var pensionär. Att ha olika funktionsnedsättningar, behöva använda vit käpp eller att sitta i rullstol upplevdes inte längre som lika avvikande som i yngre åldrar. Som pensionär var det ju också naturligt att stå utanför arbetsmarknaden, precis som andra i samma ålder.

\section{Avslutande diskussion}

Vad innebär det att åldras med funktionshinder? Hur gestaltar sig livet över tid för den som drabbats av funktionsnedsättningar tidigare i livet och sedan levt ett långt liv med dessa? Det här är frågor som det beskrivna projektet har utforskat, och diskussionen i den här artikeln har tagit sin utgångspunkt i några av projektets resultat. 
I projektet har livsloppsbegreppet fungerat både som teoretisk orientering och analytiskt redskap. Härigenom synliggörs det provisoriska och föränderliga, som med speciella förtecken präglar funktionshindrades liv. Detta i sig får betydelse för hur äldreblivandet gestaltar sig. Denna infallsvinkel har knappast tidigare belysts till exempel inom socialgerontologin, där etablerade böcker i ämnet beaktar funktionsnedsättningar som drabbar äldre, men inte äldrelivet för den som redan sedan många år har funktionshinder. På många sätt är det otypiska liv som åldrande funktionshindrade har bakom sig. Samtidigt visar resultaten att ett utvecklande och självförverkligande pensionärsliv kan vara möjligt också bland personer med omfattande funktionsnedsättningar och hjälpbehov, om man bara har tillgång till stöd och service som tillgodoser mer än de mest basala behoven. Detta utmanar såväl gerontologins (se t.ex. Blaikie 1999; Cohen 2005; Minkler \& Holstein 2005) som pensionsförsäkringsreklamens bild av det moderna och framgångsrika åldrandet.

Resultaten från delstudierna, där både retrospektiva och prospektiva metoder tilllämpats, visar på tidens centrala betydelse: Tiden med sjukdomen och med funktionsnedsättningen, tiden $\mathrm{i}$ arbetslivet, tiden med föräldrarollen etc. får betydelse för de intervjuades tolkningar av sin situation. Tiden är förknippad med förändrade innebörder. Samtidigt visar studierna hur intimt sammanflätad tiden med funktionshinder är med åldersdimensionen. Det är svårt att separera betydelsen av ålder från det faktum att de intervjuade har den icketypiska erfarenheten av att ha levt med funktionshinder i många år - och åldrats med dessa.

Livsloppsperspektivet innebär också att epoken och samspelet mellan historisk tid, med sina institutionella förhållanden, och individens tid och liv har tillmätts betydelse. Det är funktionshindrade inom vissa ålderskohorter vi fokuserat och därmed problematiserar vi också möjligheten till vittgående generaliseringar. Frågan om vilka "avtryck" epokens synsätt och reformer lämnat i de studerade gruppernas liv är komplex och kan inte besvaras på något enkelt sätt. I vissa avseenden har reformer öppnat för mer normaliserade livslopp. Samtidigt framstår det som så uppenbart att det trots reformer är problematiskt att skapa varaktig delaktighet och autonomi för de studerade grupperna. Det tycks som om delaktighet är något som kontinuerligt måste åstadkommas och underhållas. Detta synliggörs genom det långa tidsperspektivet. På samma sätt synliggörs hur autonomi är en process, och inte bara ett tillstånd något som måste skapas och omskapas gång på gång, över tid. Parallellt visar delstudie 3 , i vilken föräldrar till vuxna, funktionshindrade barn intervjuades, hur mycket av en utopi det autonoma livet var för både föräldrarna och deras vuxna barn.

Kroppens betydelse och innebörder $i$ den funktionshindrades liv har också synliggjorts. Intresset för att utforska kroppens innebörder eller funktionshindrades erfarenheter av hinder, diskriminering och motgångar har hittills inte varit särskilt starkt inom handikappforskningen (Shakespeare 2006). Betoningen av samhällets och miljöns roll i funktionshindrande processer har förvisso haft stor betydelse för att för-

Jeppsson Grassman, Holme, Taghizadeh Larsson \& Whitaker: Ett långt liv... 
ändra funktionshindrade människors livsvillkor. Men ett problem har blivit att detta synsätt alltför mycket överskuggar den personliga upplevelsen av sjukdomen eller den skadade kroppen och den individuella innebörd som dessa förhållanden har för individen. Det finns dimensioner i denna upplevelse som inte bara är avhängiga "miljön" eller en viss diskurs. Detta blir särskilt tydligt ur det långa tidsperspektiv som vårt projekt studerat. Här ansluter sig våra resultat snarare till en forskningstradition inom medicinsk sociologi som rör kroniska sjukdomar. Med tiden som instrument blir det emellertid också klart att även några teoretiska perspektiv som dominerat synen på sjukdomskriser och förlust av förmåga utmanas av våra resultat. Det gäller bl.a. ett begrepp som biografiskt brott (biographical disruption) som implicerar ett krisrelaterat oväntat brott i förhållande till det egna livet och biografin. Våra resultat visar hur begreppet inte är adekvat för att belysa sjukdomsupplevelsen över tid som snarare karaktäriseras av en serie krisrelaterade omställningar, som kan vara både oväntade och väntade på samma gång. Det här är ett område där kunskapen ytterligare behöver fördjupas.

Vidare kastar resultat från projektet nytt ljus över anhörigskapets innebörder.
Anhöriga - och inte minst föräldrar - till vuxna funktionshindrade personer tycks spela en långt viktigare roll som hjälp- och omsorgsgivare än vad som tidigare har framkommit i forskningen (Whitaker 2008; Shakespeare 2006; Jeppsson Grassman, Whitaker \& Taghizadeh Larsson 2009). I föräldraintervjuerna framträdde livsberättelser präglade av ett livslångt omsorgsansvar och som mot bakgrund av de senaste decenniernas handikappolitik och reformer väcker frågor kring i vilken mån självständighet och autonomi egentligen har uppnåtts, trots till exempel personlig assistans. Det väcker också frågor om vilket stöd och erkännande dessa anhöriga får för sina insatser. I de övriga delstudierna framgår också betydelsen av anhöriga och andra nära sociala relationer för den funktionshindrade individen. Tillgången till nära anhöriga tycks också öka i betydelse i takt med åldrandet, tillsammans med upplevelser av den instabila kroppen och ovissa framtiden.

Resultaten från projektet "Funktionshinder, livslopp och åldrande" problematiserar sammanfattningsvis och visar på luckor i etablerad kunskap inom flera områden. De visar också på betydelsen av en fördjupad diskussion av åldrandets möjliga gestaltningar. 


\section{Referenser}

Ansello, Edward F. \& Eustis, Nancy N. (1992) Aging and Disabilities: Seeking Common Grounds. NY: Baywoood.

Avlund, Kirsten (2004) Disability in old age: longitudinal population-based studies of the disablement process. Copenhagen: University of Copenhagen, Department of Social Medicine, Institute of Public Health.

Blaikie, Andrew (1999) Ageing \& Popular Culture. Cambridge: Cambridge University Press.

Bury, Michael (1982) Chronic illness as biographical disruption. Sociology of Health and Illness, 4, 2, 167-82.

Bury, Michael (2000) Health, ageing and the life course. I Simon J. Williams, Jonathan Gabe \& Michael Calnan (red.) Health, Medicine and Society. Key Theories, Future Agendas. London, New York: Routledge.

Cohen, Elias S. (2005) Disability. I Erdman B. Palmore, Laurence Branch \& Diana K. Harris (red.) Encyclopedia of Ageism. New York, London, Oxford: Haworth.

DeMarle, Daniel J. \& Le Roux, Pieter (2001) The life cycle and disability: Experiences of discontinuity in child and family development. Journal of Loss \& Trauma, 6, 1, 29-43.

Elder, Glen H. Jr., Kirkpatrick Johnson, Monica \& Crosnoe, Robert (2003) The Emergence and Development of Life Course Theory. I Jeylan T. Mortimer \& Michael. J. Shanahan, (red.) Handbook of the Life Course. New York: Kluwer Academic.

Giele, Janet Z. \& Elder, Glen H. (1998) Life course research: development of a field. I Janet Z. Giele \& Glen H Elder, (red.) Methods of Life Course Research: Qualitative and Quantitative Approaches. London: Sage.

Hareven, Tamara K. (2000) Families, History and Social Change: Life-course and cross-cultural perspectives. Boulder Colorado: Westview Press.

Hockey, Jenny \& James, Allison (2003) Growing Up and Growing Old: ageing and dependency in the life course. London: Sage.
Hughes, Bill \& Paterson, Kevin (1997) The Social Model of Disability and the Disappearing Body: towards a sociology of impairment. Disability \& Society, 12, 3, 325-340.

Jeppsson Grassman, Eva (2001) Tid, tillhörighet och anpassning. Socialvetenskaplig Tidskrift, 8, 2, 306-325.

Jeppsson Grassman, Eva (2003) "Tillhörighet och frihet. Livet med kronisk sjukdom och funktionshinder under lång tid”. I Eva Jeppsson Grassman, Sivert Antonson, Rolf Stål \& Lars Svedberg, Att drabbas och att forma sitt liv. Lund: Studentlitteratur.

Jeppsson Grassman, Eva (red.) (2008) Att åldras med funktionshinder. Lund: Studentlitteratur.

Jeppsson Grassman, Eva \& Olin Lauritzen, Sonja (red.) (2004) Normalitet och avvikelse. Samhällsvetenskapliga perspektiv på kropp, sjukdom och funktionshinder. Stockholm: Stockholms universitet, Pedagogiska institutionen och Institutionen för socialt arbete.

Jeppsson Grassman, Eva, Whitaker, Anna \& Taghizadeh Larsson, Annika (2009) Family as failure. The role of informal helpgivers to disabled people in Sweden. Scandinavian Journal of Disability Research, 11, 1, 35-49.

Kennedy, Jae (2002) Disability and Aging - Beyond the Crisis Rhetoric: Introduction to the Special Issue. Journal of Disability Policy Studies, 12, (4), 226-228.

Kohli, Martin (2005) The world we forgot: A historical review of the life course. I Robert Miller, (red.) Biographical Research Methods. London: Sage, II, 5-38.

Leisering, Lutz (2003) Government and the life course. I Jeylan T. Mortimer \& Michael. J. Shanahan, (red.) Handbook of the Life Course. New York: Kluwer Academic.

Levy, René (1996) Toward a theory of life course institutionalization. I Weymann, Ansgar \& Hienz, Walter R. (red.) Society and Biography. Interrelations between Social Structure, Institutions and the Life Course. Winheim: Deutscher Studien Verlag.

Jeppsson Grassman, Holme, Taghizadeh Larsson \& Whitaker: Ett långt liv... 
Mattsson, Sven \& Gladh, Gunilla (2005) Barn med ryggmärgsbråck blir vuxna! Läkartidningen. $102,37,2566-2570$.

Mills, Melinda (2000) Providing Space for Time. The impact of temporality on life course research. Time \& Society, vol. 9, 1, 91-127.

Minkler, Meredith \& Holstein, Martha B. (2005) Successful Aging. I Erdman B. Palmore, Laurence Branch \& Diana K. Harris (red.) Encyclopedia of Ageism. New York, London, Oxford: Haworth.

Nilsson, Sven E., Nilsson, Martin S., Nilsson, Erik D. \& Nilsson, Peter M. (2005) Långtidsöverlevnaden vid diabetes har successivt förändrats. Läkartidningen. 28-29, 2066-2070.

Närvänen, Anna-Liisa (2004) Age, Ageing and the Life Course. I Britt-Marie Öberg, Anna-Liisa Närvänen, Elisabet Näsman \& Erik Olsson (red.) Changing Worlds and the Ageing Subject. Dimensions in the Study of Ageing and Later Life. Aldershot: Ashgate.

Priestley, Mark (2003) Disability: a Life Course Approach. Cambridge: Polity Press.

Priestley, Mark (2004) A Life Course Approach to Disability Issues. I John Swain, Sally French, Colin Barnes \& Carol Thomas (red.) Disabling Barriers - Enabling Environments. London: Sage.

Putnam, Michelle (2002) "Linking Aging Theory and Disability Models: Increasing the Potential to Explore Aging with Physical Impairment". The Gerontologist, 42, 6, 799-806.

Regeringens proposition 1999/2000:79. Från patient till medborgare - en nationell handlingsplan för handikappolitiken 2000.

SFS 2008:567, Diskrimineringslag.

Shakespeare, Tom (2006) Disability rights and wrongs. London: Routledge.

Socialstyrelsen (2008) Personlig assistans enligt LASS ur ett samhällsekonomiskt perspektiv. Stockholm: Socialstyrelsen.

SOU 1991:46 Handikapp, välfärd, rättvisa. Betänkande av 1989 års handikapputredning.

Stiker, Henri-Jacques (1997) Corps Infirmes et Sociétés. Paris: DUNOD.
Strauss, D. \& Shavelle, R. (1998) Life expectancy of adults with cerebral palsy. Developmental Medicine \& Child Neurology. 40, 6, 369-375.

Taghizadeh Larsson, Annika (2009) Att åldras med funktionshinder. Betydelser av socialt och kronologiskt åldrande för människor som under lång tid levt med fysiska funktionsnedsättningar. Linköping: Linköpings universitet.

Thomas, Carol (2002) Disability theory: key ideas, issues and thinkers. I Colin Barnes, Mike Oliver \& Len Barton (red.) Disability Studies Today. Cambridge: Polity Press.

Trieschmann, Roberta B. (1987) Aging with a Disability. New York: Demos.

Verbrugge, Louis M. \&, Yang, Li-shou (2002) Aging with Disability and Disability with Aging. Journal of Disability Policy Studies, 12, (4), 253-267.

Whitaker, Anna (2004) Livets sista boning. Anhörigskap, åldrande och död på sjukhem. Stockholm: Stockholms universitet.

Whitaker, Anna (2008) Ett liv aldrig mer som andras - föräldraskap, funktionshinder och åldrande. I Eva Jeppsson Grassman (red.) Att åldras med funktionshinder. Lund: Studentlitteratur.

Williams, Simon J. (2000) Chronic illness as biographical disruption or biographical disruption as chronic illness? Reflections on a core concept. Sociology of Health and Illness, 22, (1), 40-67.

Williams, Gareth \& Busby, Helen (2000) The politics of 'disabled' bodies. I Simon J. Williams, Jonathan Gabe \& Michael Calnan (red.) Health, Medicine and Society. Key Theories, Future Agendas. London, New York: Routledge.

Zarb, Gerry \& Oliver, Michael (1993) Ageing with disability. What do they expect after all these years? London: University of Greenwich.

Zarb, Gerry (1993) "Forgotten but not gone". The experience of ageing with a disability. I Sara Arber \& Maria Evandrou (red.) Ageing, Independence and the Life Course. London: Jessica Kingsley Publishers. 


\section{Summary}

\section{A long life with a particular signature. Life course and ageing for people with disabilities}

What does it mean to age with disability? How does the early onset of disability shape life over time for those who live with chronic illness? These are examples of questions which disability research, to date, has taken little interest in, despite the fact that disabled people in our time have improved chances of long lives. Equally, there is a lack of research concerning the family perspective: what does it mean to be an ageing parent, yet still a caregiver to an adult disabled child? The aim of this article is to discuss these issues. The analysis is mainly based on results from a broad research project in which these questions have been studied.
The results indicate the importance of the time concept and its connotations - such as biographical time and historical time - for the understanding of the lives and ageing of disabled people. Furthermore, the life course perspective underlines the instability of many impairments: the level of functioning is an ongoing transitional process, and uncertainty about the future is a central theme. The results challenge established knowledge within different fields regarding concepts such as full participation, autonomy, biographical disruption and the prerequisites of active ageing. 